\title{
New Arenas For Small Media \\ Towards an Ethnological Exploration of Family Cinema
}

\author{
Dr. Alex Vailati \\ Post-doctoral Fellow at the Center of Visual Anthropology (NAVI) of \\ the Federal University of Santa Catarina (Brazil)
}

\begin{abstract}
The advent of cheap, user friendly, video technology has created a huge revolution in representational agency. Videos are now made by production units that are at times comprised of families, churches, music groups, community associations or individuals. In this way, videos produced and distributed within local and atypical networks profoundly shape contemporary imaginaries. This article is an analysis of the so called family cinema phenomenon that is still peripheral in ethnological research. The analysis of experiences of "family film archives", a recognized field of studies for historical sciences, shows for example how these media become "memories" of events for families and individuals. This article will address the importance of field-based research on how "local videos" are produced from an economic, political and aesthetic perspective. This can be a key strategy for understanding how imaginaries are "locally produced" and how they relate to global narratives.
\end{abstract} Keywords: Video production, Family cinema, Ethnography of imaginaries, Small media

\section{Resumo}

O advento da tecnologia de vídeo barata, fácil de usar, criou uma ampla revolução nas estratégias representacionais. Atualmente, os vídeos são feitos por unidades de produção não profissionais que são, por vezes, compostas por famílias, igrejas, grupos musicais, associações comunitárias ou indivíduos. Dessa forma, os vídeos produzidos e distribuídos em redes atípicas, moldam profundamente o imaginário. Este artigo é uma análise do assim chamado fenômeno cinema de família, que é ainda periférico na investigação etnológica. A análise das experiências dos "arquivos de cinema de família”, um campo 
reconhecido de estudos para as ciências históricas, mostra, por exemplo, como essas media tornam-se "memórias" de eventos para famílias e indivíduos. Esse artigo irá abordar a importância da pesquisa de campo com base em como os "vídeos locais" são produzidos, de um ponto de vista econômico, político e estético. Pode ser a estratégia fundamental para compreender como os imaginários são "produzidos localmente" e suas relações com narrativas globais.

Palavras-chave: Produção de vídeo, Cinema de família, Etnografia do imaginário, Informal media 


\title{
New Arenas For Small Media \\ Towards an Ethnological Exploration of Family Cinema
}

\author{
Dr. Alex Vailati \\ Post-doctoral Fellow at the Center of Visual Anthropology (NAVI) of \\ the Federal University of Santa Catarina (Brazil)
}

\section{From Nollywood to home}

When Flaherty was shooting his masterpiece among the Inuit almost one hundred years ago, he probably did not realize that one day Nanook, the protagonist of his film, would be able to make his own movie. Nevertheless, Flaherty's work (1922) paved the way for visual research, a legacy that is particularly important to cultural anthropologists.1 There has been considerable debate about his movies in the history of anthropology and cinema. Nowadays, Flaherty is usually recognized by many authors as the "inventor of documentary". It is also easy to find descriptions that emphasize his quality as a bricoleur. This is a well-known category in cultural anthropology, which describes an agent with creative faculties who is able to join different cultural objects, narrations and images, to produce new imaginaries. Flaherty's contribution was to combine cinema with an indexical description of reality. Moreover, his work does not aim towards an objective realism. His camera work highlights collaboration with the subjects, a process that is implicit in all ethnographies, whether visual or written.

While Flaherty's creative results were huge commercial successes and also well received by scholarly criticism, other authors remained unknown. One hundred years later, we find a different relationship between filmmakers' works and their reception. Media studies have clearly demonstrated the consequences of the revolution that has transformed media production (Ginsburg, Abu-Lughod, Larkin 2002). This is particularly clear in terms of

1 It is also interesting to note that Flaherty "invented" visual field work, almost at the same time as Malinowski (1922) invented fieldwork. The aim of both authors was to propose a narration from the "native" point of view. The main difference is that Flaherty implicitly uses a fictional model to construct this narration. 
motion pictures. While film production had once been unidirectional due to its costs, it is now definitely a multi-centered practice. In the last fifteen years, simpler and less expensive technologies, such as digital video, cell phones with cameras and Internet accesses have become available. They have allowed the diffusion of filmmaking to groups or societies that could previously only contemplate cinema as receptors. Contemporary visual anthropologists have perceived this transformation (Peterson 2003; Rothenbuhler, Coman 2005). Working mostly with a collaborative approach in various geographical contexts, ${ }^{2}$ I have carefully observed the diffusion of inexpensive video cameras ${ }^{3}$, over the past five to ten years. This phenomenon may be different in each local context, but the advent of lowcost video production is now detectable in places that are very far from urban spaces and increasingly popular in low-income areas.

The case of collaborative video is emblematic of these processes. In the past, it was used in areas considered "backward" from a technological point of view, with the idea of connecting them to "modernity" (Appadurai 1996; Pink 2007), especially due to its innovative symbolic dimension. In ethnographic literature, audiovisual tools are usually described as something "new" that have been introduced to the field by researchers. The classic work by Sol Worth and John Adair is a good example (Worth, Adair 1970). This situation appears to have radically changed with the advent of low-cost digital video technology which has now become an everyday part of people's lives. Over the past eight years I have conducted extensive fieldwork in rural regions of South Africa where these transformations are highly visible (Vailati 2011). From the use of cell phone cameras to the production of low-cost DVDs by musical groups or churches, audiovisual production is a widely diffused practice.

Since the classic work about the Iranian Revolution (SrebernyMohammadi \& Mohammadi 1994), ${ }^{4}$ the so-called "small media" has become

2 I started working with collaborative video in Italy in 2007. But, two main projects are the source of data here. The first developed in rural KwaZulu-Natal, South Africa (2009-2010) and the second in the municipality of Florianópolis, Brazil (2011-2012).

3 "Low cost" is a difficult category to define. This is because it is related to the social context in which the social actors are living. But it is clear that today it is easier to define video as "low cost". In fact, video cameras are now found in cellphones and other small devices that are widely diffused even among lowincome communities.

4 This book pays close attention to the role of so called "small media" in broadcasting revolutionary discourses in Iran. Scholars who used this concept were referring in particular to audiocassettes. Since 
a research topic. Larkin's work on the so-called "Nollywood" system and its video production practices, is a good example. His use of the category small media is useful, especially because films were distributed mostly illegally, on videocassettes or DVDs. I use his definition in this article: "small media refers to technologies such as video - and audiocassettes, photocopiers, faxes, and computers, which differ from older 'big' mass media of cinema and television and radio stations" (Larkin, 2000: 219). Audiovisual images, diffused through videocassettes, were, according to Larkin, the "quintessential small media" (Larkin 2000: 220). These reflections were written more than ten years ago, an enormous amount of time in relation to the speed of technological transformations.

Because of its low cost and the requirement of only basic computer literacy video production proliferates exponentially, from short clips recorded by individuals to more complex productions such as the recording of family ceremonies or music videos. These examples represent only a few types of production; but they provide an idea of the complexity of this field of study. In this article I analyse recent literature on this topic in order to connect anthropological reflection and ethnological experimentations to a new research field, that of family cinema.

\section{Re-producing imaginaries}

It is currently common to find DVDs on the living rooms shelves in many homes. These DVDs often depict moments in the inhabitants' life. Developing a theoretical approach to these objects is a complex task. First, I address the concept of imaginary, which is one of the most complex conceptual categories in the contemporary social sciences and has increasing importance.

The imaginary is often used to describe objects located between sociocultural contexts and individual psychological faculties. It appears in studies of transnational systems, such as the visual and broadcast and print media. At times, the concept nearly suffers from overuse. This may be because from many points of view it is indispensable. The imaginary is an emerging tool in the description of the "data networks" from which individuals now commonly draw freely to renegotiate the meanings of their daily lives. It is interesting

then, the idea of "small media" has been used to study many different types of media. 
to note that the term "imaginary" refers primarily to images, an object that, through the recent media revolution and the widespread diffusion of communications, is having increasing influence on even more "peripheral" contexts.

To define "imaginary" would require a complex discussion, which is not the purpose of this paper. However, I would like to refer to can emphasize some aspects that emerge from the literature, that crosses several disciplines. The ambiguity of the relationship between the imaginary and what we might call "reality" is perhaps the first. Sartre defined it as a "denial of reality" (Sartre, 1936), in an obvious reference to Marx. The French philosopher affirmed that the imaginary and the imagination are terms directly related to an ideology. Moreover, he maintained that they served in general to mask material processes of life.

The imaginary is thus closely related with the political processes that affect social life. The philosopher Charles Taylor, offers an interesting perspective on the relationship between imagination and power. Taylor reflects primarily on the concept of the modern public sphere, describing it, as a "metatopical" common space not located in a specific place (Taylor 2004). The spread of these types of spaces for Taylor is the consequence of the increased role of the press in Europe, since the $18^{\text {th }}$ century. This process has become more significant with the diffusion of television. Images conveyed by print media or video travel beyond the context in which they are produced. The public sphere to which Taylor refers is constructed, in modern times, mainly through the use and re-use of these images. Public sphere influence political power but it is not directly controlled by it (Taylor 2004).

The expulsion of the imaginary from the political sphere and its influence on it describes the basic ambiguity of this concept. While the imaginary is in fact the product of metatopical social and political processes, it strongly influences local contexts. But at this level, it is located in the creative act of an individual who draws from this space to imagine his or her social life. Imaginaries influence how individual lives are intertwined with those of others, their expectations, as well as the deeper normative notions and images that underlie these expectations (Taylor 2004).

The imaginary is therefore a concept that is useful for analyzing the relationship between an individual and the flow of images and narratives diffused by contemporary media and new media. Psychoanalysis is probably the scientific domain in which the imaginary, understood as psychic function, 
has been explored most deeply. Castoriadis, a philosopher strongly influenced by Lacan, affirms that the individual is "preceded" by the imaginary, (Castoriadis 1975), to emphasize its strong, unconscious influence. But he also highlights an opposite effect. Castoriadis in fact defines imaginary as the most radical faculty of the individual, which allows "re-semanticizing" social objects that surround him. The individual is endowed with the power to create images that include symbolic objects that do not exist within so-called reality (Castoriadis, 1975). Without claiming to exhaust this complex debate, it is interesting to note that the imaginary acquires a double meaning as both constrictive and creative. This reflection shows how an individual is both a passive receiver of meaning but, is also able to produce new meaning.

Anthropological theory has only recently explicitly addressed the theme of imaginary, and has examined it in connection with the increased strength of the mass media and transnational migrations (Appadurai 1996). The imaginary appears in this sense as a response to the increasing interconnections, detectable even in remote ethnographic contexts, between these localities and global narratives. According to Appadurai the capillary action with which the contemporary media are capable of conveying information has "spread" the imaginative faculty (Appadurai 1996: 18). He argues that "thanks to the media, not only charismatic leaders are now able to use creative imagination, but even ordinary people have acquired this ability" (Appadurai 1996: 19).

Recent anthropological studies have highlighted the strong coercive dimension of imaginary. The analysis of African colonial society is a good example. The role of the imaginary that emerges from postcolonial studies is closely connected with the establishment of cultural hegemony. The relationship between colonizers and the colonized was often read, especially in the context of postcolonial studies, as a result of the production and recognition of highly contiguous imaginaries (Mbembe 2000). In this sense, the work of the colonizer was based on an image of "the native" described through the symbols denoting them as primitive and ingenuous. This allowed the use of a concept of power based on "control" which was simultaneously a kind of "colonizer's burden" (Mbembe 2000: 47). From the colonized perspective, this led to the violent imposition of a representation conveyed through a complex set of narratives. The imaginary in this case appears essentially as an act of coercion that is unilaterally imposed through a single narrative, which definitively denies any possibility for re-action. The debate, even within cultural 
anthropology, seems to assume connotations similar to those found in other disciplines. Ethnological research, due to the importance it gives to local context, may provide important data for this discussion. For example, taking as a starting hypothesis Appadurai's proposal, ethnography may investigate the role of imaginative faculty in a given context and the symbols and images that are produced and used (Appadurai 1996).

The imaginary is thus a useful concept for this analysis, because it is contrary to what can be considered as "culture". It is not the property of a single minority and located in a specific context. The interesting aspect of the social imaginary is that it is shared by large groups of people, located in different geographical spaces. (Taylor 2004). The imaginary is therefore conceivable as an archive of images, symbols and narratives to which people can freely draw on to describe and give a "sense" to their daily activities. If culture can be understood as a particular system of symbols, images and narratives, which is adopted by a single social group, the imaginary can be considered as a basin from which people can draw from to form those systems of symbols that govern society.

\section{The study of small media}

As I mentioned above, the small media entered the realm of the social sciences more or less in the early 1980s. In this period, most studies were focused on the "non-hegemonic" function of small media. Following Ribeiro, some practices, if analyzed in this systematic dimension are:

“non-hegemonic and not anti-hegemonic because its agents' aims are not to destroy global capitalism or establish some radical alternative to the prevailing order. It is non-hegemonic because its activities challenge the economic establishment, both at national and international levels" (Ribeiro, 2010: 29). ${ }^{5}$

The case of Nollywood is extremely interesting in this regard. This term is used to define the Nigerian video production system that, since the early 1990s has become one of the world's most prolific film production industries,

5 My translation of: "não-hegemônico e não de anti-hegemônico porque seus agentes não intencionam destruir o capitalismo global ou instalar algum tipo de alternativa radical à ordem prevalecente. É nãohegemônico porque suas atividades desafiam o establishment econômico em todas as partes, nos níveis locais, regionais, nacionais, internacionais e transnacionais”. 
in terms of the number of movies produced. In the first instance, its name is clearly not hegemonic, but represents an alternative to hegemonic systems such as Hollywood or Bollywood. Moreover, Nollywood films are usually illegally duplicated and informally distributed (Haynes 2000). This contrasts with the main, often hegemonic, distribution channels of multinational cinema.

Most Nollywood films, until at least ten years ago, were low-budget productions, made with cheap equipment. Moreover, their dissemination was based mostly on the films' commercial success and not on "artistic pretensions". Nevertheless, Nollywood films were based on a specific film language that combined a multiplicity of themes closely related with Nigerian society. Over the years, Nollywood films have become more than a "business operation" to become a strong symbolic resource for Nigerians. Recent studies have focused on films as tools used by migrant workers to re-negotiate their subjectivity during migration processes. Films are produced in contexts of migration and distributed in Nigeria. In this way, migrants' views can be seen back home.

Nollywood thus represents an emblematic case for the negotiation of the imaginary that permits a reaction to heteronomic representations. This case moreover is only the most famous, but it is possible to state that video is becoming a global tool for the negotiation of representation. In Nigeria, the space left empty by the development of a "traditional Western cinema" has allowed this experimentation. The Nollywood experience has been a pioneer for all of Sub-Saharan Africa. The production of audiovisual material by churches is an example. In this case, over the past 20 years video has become a tool to diffuse the messages of churches. In many African locations, local television stations now broadcast sermons of the most important pastors. But in the "peripheries" of video production, cheap DVDs of the sermons of local preachers can be purchased in local markets.

South Africa is a nation where the diffusion of television signals has grown parallel to the diffusion of DVD players ${ }^{6}$. In rural Zululand for example, television is now related to the ability to "get in touch" with other people. "To be seen" on TV seems to establish a relation of proximity between the "broadcasted" and "the viewer" (Vailati forthcoming). Moreover, it appears

6 The South Africa Broadcasting Company was founded in 1976. But inhabitants of rural areas, who during apartheid were confined to specific areas, had been without television until almost ten years ago. 
that local DVDs are sometimes preferred over the leading national television broadcaster. They are perceived as more "functional" both for their "realism" and for their power to entertain. This observation of everyday life seems related to phenomena presented in the first studies of small media. In revolutionary Iran, for example, it was found that "informal cultural spaces may become politicized particularly through the effective use of small media and group communication" (Sreberny-Mohammadi \& Mohammadi 1994: xxi). In the same way, the contiguity among producers and receivers allows a new perception of media.

In order to study this transformation from an emic point of view it is useful to consider the contribution of anthropology and in particular visual anthropology. For almost 50 years anthropology has developed research tools that began in the "peripheries of power." Visual anthropology was pioneer in the analysis of so called "native video production." An important study in this regard is the Navajo Film Project, of the 1970s. This endeavor "taught the "native" to use the camera and to do his own editing of the material he gathered" (Worth, Adair 1970: 10). The goal of the researchers was to study visual communication. However, their research program implicitly includes a collaborative project between the anthropologist and natives: "Making such films required the cooperation of the subjects being photographed" (Worth, Adair 1970: 10). The process paved the way for the next generation of scholars.

Since the early 1970s, several anthropologists have built long term relationships with local communities. The best-known examples are the experiences of Turner with the Kayapo of Brazil (Turner 1992) and Michaels with the Aboriginal people of Australia (Michaels, Kelly 1984). In this work it is important to reflect on the consequence of the anthropologist's presence in the field: this presence is not understood here as passive but as active participation in the lives of people. These experiences with participation have been the first attempts to study audiovisual media among "non-Western" populations. In these experiments, the "subjects" of anthropological research are able to produce representations of their lives, cultures and societies. Furthermore these analyses have laid the groundwork for the media anthropology that now has a significant role in the anthropological debate (Ginsburg, AbuLughod, Larkin, 2002; De Largy Healy, 2004). 


\section{Conserving small media}

The relationship between "professional" ethnographers and "natives" is thus a topic that has been grasped by anthropology. Audiovisual productions made by informants are now fully recognized as "films" (Videos Nas Aldejas). In cinema studies of the last twenty years, for example, more space has been given to what has been called "amateur cinema". As Zimmermann states,

"the deficit of historical study on amateur film boldly underscores the power of 'professional' film and the degree to which film studies' is enamored with it to marginalize the aberrant, the primitive, and the undeveloped phenomenon of amateur film and its corollaries" (Zimmermann 1995: x).

It is difficult to define an amateur, which is a category constructed as a mirror to differentiate professionals from "the rest". As observed many times in history, this is a clear process for the construction of alterity, which is very similar to Edward Said's classic description of the construction of Orientalism (Said 1979). Under the influence of Taylorism "amateurs" are created only to reinforce the status of "professionals."

The rehabilitation of amateur production has inspired a series of studies over the past 20 years. Film exhibitions have followed these studies, and there has been a slow but ongoing tendency to create archives of these films. Amateur film productions are now clearly recognized as "memories", and valuable documents that must be conserved. The definitive eclipse of the Super 8 recording format has been an important stimulus to this process. In the 196os, Super 8 which was low cost and easy to use became the most important medium for what has been called "family cinema". Its almost complete abandonment has created an urgent need to conserve films made in this format.

The category that is most widely used in this discussion is "family cinema”. This is an important distinction from an anthropological perspective. First, it allows us to place this kind of film production in the universe of the European or North American middle class. Puissant correctly asks:

"La caméra ne constituerait-elle pas un moyen d'appropriation du monde extérieur plus valorisant que l'univers familier, considéré comme banal intuitivement connu ou que la famille ne serait-elle plus qu'un prétexte de découverte de ce monde extérieur?” (Puissant 2005: 12).

The - imagined - relevance of the nuclear family as an institution in the 
Western world has placed it as the primary object of "amateur" representational strategies. This establishes a need to preserve "family cinema" as memories or data for further research. Moreover, the relevance of this material is underlined by its power to de-construct. Due to its ability to be indexical, family films can depict family life from an important angle. While the nuclear family structure is normally considered as the standard for Western civilization, the "camera eye" sometimes has the ability to show atypical configurations of this family. The camera may underline characteristics or tensions within kinship. The camera operator, who may be a father or uncle, describes his affective universe through the camera movement. The reaction of children or nieces and nephews who appear in the movie can also express a "thick description" of their expectations.

Elicitation also appears to be an interesting operation that can lead to interesting results. Simoni, explaining the experience of the Home Movie Association, an Italian archive of family cinema, stated:

The reactions are multiple. The amateur usually shows his films long after their realization. He is normally proud to be "discovered", and guides spectators through his films' viewing. If he has died, his son or his nephew tries to present him in the best way. The person who was filmed, who watches old images of himself, is normally astonished. Images show how he was many years ago or past moments of his life. ("I saw things that were forgotten. I thought that never happened") (Simoni 2004:3)

The power of family movies as support for memory is made clear here. Elicitation is a tool of visual anthropology that has been widely explored in the realm of still pictures. The same work on audiovisual memories provides new opportunities for this kind of research. While still images seem to have a "natural" presence in family memories, audiovisuals appear to have a different status. Several discussions with people from different social classes, in Europe, have revealed a tendency to "forget" family films.

7 My translation of: "Le reazioni sono le più varie. Il cineamatore spesso mostra per la prima volta, e in generale dopo molto tempo, immagini da lui stesso girate: è giustamente orgoglioso di essere scoperto, guida il nuovo spettatore alla visione dei suoi film. Se il cineamatore non c'è più, è il figlio o il nipote a cercare di valorizzarlo. La persona filmata, di fronte alle immagini che lo mostrano com'era tanti anni prima o che restituiscono certi momenti e situazioni del proprio vissuto, piuttosto si stupisce ("Ho visto cose dimenticate e che pensavo non fossero mai accadute")". 
Usually left in a closed drawer, films can go years without being viewed. The rapid evolution of technical equipment necessary for their reproduction is also an important factor. Equipment to reproduce films is quickly disappearing. These memories are conserved but progressively forgotten. Photography thus seems to be the most important medium used by the family to remember the past.

These examples offer only a small picture of the possible results of a study of family cinema. While there are many examples of this type of study with still pictures, there is much to be explored through the study of moving images. The richness of this material helps explain the progressive attempt to conserve them. In the last twenty years a number of archives have been established. These are usually small institutions established solely for the purpose of conservation. They have a strong link with the local context, and are dedicated to collecting and conserving the film production of local "amateurs." Some examples are the Italian Association of Home Movies (Homemovies), The Centre for Home Movies (Centre for Homemovies) located in the United States and the Japanese Film Preservation Society (Film Preservation Society). In recent years these national institutions have also begun to express an interest in 'amateur cinema'. Foster has argued that the National Film Preservation Foundation that was brought into being by the American Congress in 1996 is evidence of the importance government has attached to these productions (Foster, 2010: 13).

Recently, the Cinemateca Brasileira (Cinemateca Brasileira) has established a department for the conservation of home movies. Considering the interest in these materials it is possible to suppose that there will be an increase in studies and projects about them be in the future.

\section{Towards ethnological explorations}

My aim now is to try to connect ethnological research to these conservational projects that have been undertaken basically by historians and cinema scholars. These materials can be analyzed from the perspective of the producers, at the time of their production. The fictional film "Amator" (Camera Buff in English) by Polish director Kieslowski (1979) provides a good description of the encounter with video technology.

The main character of this film is a man who buys a Super 8 camera to 
film his first born child. He becomes progressively obsessed with the production of moving images. This path leads him to a "professional" status, but also compromises his family stability. The protagonist experiences what Rouch called "cinetrance", (Rouch 1971) in which the view of the world through the camera progressively changes his relations with others, principally with his family. His wife is the first to perceive his changes although society also comes to recognize his new status, as director. As a director, he experience life in a new way. In this film, Kieslowski clearly affirms that the production of images is not a neutral process, but involves an inner transformation. Moreover, this process has strong social consequences ${ }^{8}$.

The film was released in 1979. More than thirty years later, domesticvideo production is now diffused worldwide. As I have already stated, while domestic video production was once a practice restricted to the elite, it is now accessible to low income people. The case of Video Nas Aldejas [Video in the Villages] is an interesting example. This is a project that has fostered video production among Brazilian indigenous people. It has been active in the Amazon for 25 years. Low-cost and light-weight video technologies are utilized and the videos are now distributed through websites. This experience permitted the study of,

"the potential of this tool. This experience was realized with other groups, producing a video series on how each group incorporated video in its own way" (Video Nas Aldejas).

Here the embodiment of video in a particular cultural system is one of the main objects of analysis.

I sought to replicate this experience in rural Zululand, my principal research field. Little by little, the relevance of local video production has been revealed. The connection with family cinema was apparent. The presence of cameras was common at family rituals or celebrations. The camera was primarily a mark of social relevance for the organizers of the family event. For

8 Another interesting analysis is proposed by Zimmerman (1995). It concerns the movie Peeping Tom, (Powell 1960) where the protagonist has been the object of his father's psychological experiment. His father used to film his son's reaction to pain. When he grows up, the protagonist becomes a killer that films his murders.

9 My translation of: "do potencial que o instrumento apresentava, esta experiência foi sendo levada a outros grupos, e gerando uma série de vídeo sobre como cada povo incorporava o vídeo de uma maneira particular". 
this reason, video production by families who can afford it is conducted by a "professional-amateur." This is a paid video maker who shoots and edits the movie. A second interesting factor is that the film is usually screened many times in the homes of family members. At times the video becomes, like Nollywood productions, something that can be sold, and distributed, particularly within the family network, but at times even beyond it.

The transcultural study of this kind of production can provide much data on what is called here the "production of imaginaries". This can shed light on representational strategies and on how persons and symbolic objects are included in films. Referring to the case of rural Zululand, my presence was often an interesting factor. I was usually the only white person at the ceremonies and in the videos. I have generally been represented ambiguously. In one case, the filmmaker clearly sought to use my presence to emphasize the protagonist's social network. As a white researcher - and friend of the ceremony's organizers - my presence was an important social distinction for the family. But moreover, the filmmaker used representational strategies to highlight the difference between myself and the others by using video effects.

This case is emblematic. It emphasizes creative strategies in the use of video technology. The narration produced is a mirror of the local social context and also expresses individual agency. Moreover, it sheds light on how further memories are produced. Visual anthropology can thus provide data about the contemporary video revolution and complement the large body of research on family cinema conducted by other disciplines. While these transformations are already considered history in Western neoliberal societies, in other parts of the world, local, creative and original solutions are also produced daily. The construction of contemporary social imaginaries, in between hegemony and non-hegemony, is a result of these processes.

\section{References}

\subsection{Bibliography}

APPADURAI, Arjun. 1996. Modernity at large: cultural dimensions of globalization. Minneapolis: University of Minnesota Press.

APPADURAI, Arjun. 2000. "Grassroots globalization and the research imagination". Public Culture, 12(1): 1-19.

CASTORIADIS, Cornelius 1975. L’institution imaginaire de la société. Paris: Seuil. 
CENTRE FOR HOMEMOVIES. < http:/|www.centerforhomemovies.org/ > Accessed on March 2012

CINEMATECA BRASILEIRA. < http:/|www.cinemateca.gov.br/ > Accessed on March 2012

DE LARGY HEALY, Jessica 2004, "Do trabalho de campo ao arquivo digital: performance, interação e Terra de Arhnem, Australia”. Horizontes Antropoloógicos, 10(21): 67-95.

DURINGTON, Matthew 2004. “John Marshall's Kalahari Family”. American Anthropologist, 106: 589-594.

FILM PRESERVATION SOCIETY. < http://www.homemovieday.jp/english/ about.html > Accessed on March 2012.

FORSTER, Lila S. 2010. Filmes domésticos: uma abordagem a partir do acervo da Cinemateca Brasileira. MA Thesis Unpublished, Universidade Federal de São Carlos - São Carlos

GINSBURG, Faye. 1991. "Indigenous media: faustian contract or global village?”. Cultural Anthropology, 6: 92-112.

GINSBURG, Faye. 1991. ABU-LUGHOD Lila; LARKIN, Brian (org.). 2002.

Media world. Anthropology on new terrain. Berkeley-Los Angeles-London: University of California Press.

HAYNES, Jonathan (org.). 200o. Nigerian video culture. Athens: Ohio University Press.

HOMEMOVIES. < http://www.homemovies.it/ > Accessed on March 2012.

LARKIN, Brian. 2000. "Hausa dramas and the rise of video culture in Nigeria". In: J. Haynes (org.), Nigerian video culture. Athens: Ohio University Press. pp. 209-241.

MALINOWSKI, Bronislaw K. 1922. Argonauts of the Western Pacific. An account of ntive enterprise and adventure in the archipelagoes of Melanesian New Guinea. London: Routledge \& Kegan.

MBEMBE, Achille. 2000. On the postcolony. Berkley: University of California Press.

MICHEALS, Eric. 1985. “Constraints on knowledge in an economy of oral information”. Current Anthropology, 26(4): 505-510.

MICHEALS, Eric; FRANCIS, J. Kelly. 1984. "The social organization of an aboriginal wideo Workplace”. Australian Aboriginal Studies, 1: 28- 49.

NATIONAL FILM PRESERVATION FOUNDATION. < http://www.

filmpreservation.org > Accessed on March 2012.

ODIN, Roger (org.). 1995. Le film de famille: usage privé, usage public. Paris: 
Meridiens Klincksieck.

PETERSON, Mark A. 2003. Anthropology and mass comunication. Media and myth in the new millennium. Oxford: Berghahn Books.

PINK, Sarah (org.). 2007. Visual interventions. Applied visual anthropology. New York- Oxford: Berghahn.

PUISSANT, Jean. 2005. "Le film de famille, composante nécessaire de la mémoire collective”. In: N. Tousignant (org.), Le film de famille. Bruxelles: Facultés Universitaires Saint-Louis. pp. 8-14.

RIBEIRO, Gustavo L. 2010. "A globalização popular e o sistema mundial não hegemônico". Revista Brasileira de Ciências Sociais, 25(74): 21-37.

ROTHENBUHLER, Eric W.; , Mihai (org.). 2005. Media anthropology. London: Sage.

ROUCH, Jean. 1971. "On the vicissitudes of the self”. Studies in Visual Communications, 5(1): 2-7.

SAID, Edward. 1979. Orientalism. New York: Vintage.

SARTRE, Jean-Paul. 1936. L’imagination. Paris: PUF.

SIMONI, Paolo. 2005. "La nascita di un archivio per il cinema amatoriale: il caso dell'Associazione Home Movies”. Comunicazioni Sociali, 3: 1-7.

SREBERNY-MOHAMMADI, A.; MOHAMMADI, A. 1994. Small media, big revolution. Communication, culture, and the iranian revolution. Minneapolis: University of Minnesota Press.

TAYLOR, Charles. 1992. Multiculturalism and "the politics of recognition". Princetown: Princetown University Press.

TAYLOR, Charles. 2004. Modern social imaginaries. London: Duke University Press.

TOMASELLI, Keyan. 1989. "Transferring video skills to the community. The problem of power”. Media Development, 4: 11-15.

TOMASELLI, Keyan. 1996. Appropriating images. The semiotics of visual representation. Højbjerg: Intervention Press.

TURNER, Terence. 1992. "Defianti. The Kayapo appropriation of video". Anthropology Today, 8(6): 5-16.

VAILATI, Alex. 2011. La trasmissione imperfetta. Conoscenze e immaginario tra generazioni di uomini del KwaZulu rurale. PhD Thesis Unpublished, University of Turin - Turin.

VAILATI, Alex. (forthcoming). "Seeing in distance. Video production among rural south african youth. Visual Anthropology. 
VIDEOS NAS ALDEIAS. < http:/|www.videonasaldeias.org.br/> Accessed on March 2012.

WORTH, Sol; ADAIR, John. 1970. "Navajo filmmakers". American Anthropologists, 72(1): 9-34.

WORTH, Sol; ADAIR, John. 1972. Through navajo eyes. An exploration in film communication and anthropology. Bloomington/ London: Indiana University Press.

ZIMMERMAN, Patricia R. 1995. Reel families. A social history of amateur films. Bloomington: Indiana University Press

\subsection{Filmography}

Navajos film themselvess. John Adair, Sol Worth. United States, 1966.

Kayapo out of forest. Micheal Beckam. England, 1989.

O espírito da Tv. Vincent Carelli. Brasil, 1990. Nanook of the North. Robert Flaherty. Canada, 1922.

Camera buff(Amator). Krzysztof Kieslowski. Poland, 1979.

Photo wallash. David Macdougall. Australia, 1992.

A kalahary family. John Marshall. United States - South Africa, 2007.

Cannibal tours. Dennis O’Rourke. United States, 1987.

Peeping tom. Micheal Powell. United States, 1960.

Moi, un noir. Jean Rouch. France, 1959.

Cronique d'un été. Jean Rouch; Edgar Morin. France, 1961.

\section{About the author}

Alex Vailati received his $\mathrm{PhD}$ in Anthropology and Ethnology at the University of Turin (Italy) with a dissertation on South African rural youth and their imaginary. He has been Research Affiliate to The Centre for Communication, Media \& Society of the University of KwaZulu-Natal (South Africa). Since 2011 he is Post-doctoral Fellow at the Center of Visual Anthropology and Images' Studies (NAVI) of the Federal University of Santa Catarina (Brazil)

\section{Main publications and films}

VAILATI, Alex (forthcoming). “Seeing in Distance. Video production among rural South African youth". Visual Anthropology. 
VAILATI, Alex 2012. Slow Walker (film). Italy, Brazil, $52 \mathrm{~min}$.

VAILATI, Alex (Org) 2011. Un rifugio dall'esclusione. L'accoglienza non istituzionale dei richiedenti asilo a Torino. Torino: L'Harmattan.

VAILATI, Alex 2011. La trasmissione imperfetta. Conoscenze e immaginario tra generazioni di uomini del KwaZulu rurale. Torino: PhD Thesis Unpublished, University of Turin.

INGUAGGIATO, Carla, NAVARRA, Cecilia, VAILATI, Alex 2010, The role of rural producers' association in development process: an introduction to the case of Morrumbala, Mozambique, Roma, Quaderni del DIEs - Università La Sapienza.

INGUAGGIATO, Carla, NAVARRA, Cecilia, VAILATI, Alex (Org), 2009, Il ruolo delle associazioni produttive agricole nei processi di sviluppo. Il caso di Morrumbala, Mozambico, Torino, L’Harmattan.

\section{Contact details}

Address: Programa de Pós-Graduação Interdisciplinar em Ciências Humanas Campus Universitário - Trindade - CEP 88.040-900 - Florianópolis - Santa Catarina - Brasil

Telephone: (+55) 4899826050

E-mail: alexvailati@gmail.com

Received April 30, 2012. Approved May 14, 2012. 